- Describes how recognition of a 'ship of teeth' led to identification of the skull, disguised as a map of Utopia, with which Ambrosius Holbein had illustrated the third edition of Sir Thomas More's book.

- Draws attention to the part played by experience in dental radiology in heightening the perception of concealed anatomical structures.

- Discusses the commissioning of the 'map' by Erasmus of Rotterdam, and suggests what viewers in the early sixteenth century might have made of the picture.

\title{
Ambrosius Holbein's memento mori map for Sir Thomas More's Utopia. The meanings of a masterpiece of early sixteenth century graphic art
}

\author{
M. Bishop ${ }^{1}$
}

This paper describes how, and asks why, the Renaissance artist Ambrosius Holbein hid a skull within the overall design of his woodcut map of Sir Thomas More's Utopia. (Fig. 2) This map was prepared for the 1518 Froben edition of the book, and was probably commissioned by Erasmus of Rotterdam. Its identification now is made easier by the habits of interpretation with which all dentists are equipped thanks to their skill in dental radiology, and by the recognition of teeth appearing in an unlikely disguise.

Ambrosius Holbein (1494/5-1519/26, depending on source), was the gifted elder brother of Hans Holbein (1497-1543, known as 'the younger', as their father was also Hans and an artist), who is the better known of the two in England, where he became Court Painter to Henry VIII in 1536. Hans painted portraits of Erasmus (1523), and of More with his family (1526), and he is celebrated in medical circles for his monumental painting of the King presenting the 'Charter' (actually the Act of Parliament) of Union to the barbers and surgeons at Bridewell Palace in 1540. ${ }^{1}$

In 1533 Hans played with the laws of perspective when he included an enigmatic anamorphic skull in his painting The ambassadors. This paper shows that 15 years earlier Ambrosius had played as clever a trick with the minds of the viewers of his Utopian map.

\footnotetext{
${ }^{1}$ Queen Anne House, 2A St Andrew Street, Hertford, Hertfordshire, SG14 1JA
}

Correspondence to: Mr Malcolm Bishop

\section{Refereed Paper}

Received 14.02.04; Accepted 29.07.04

doi: 10.1038/sj.bdj.4812526

๑ British Dental Journal 2005; 199: 107-112
Hans' Ambassadors, and Ambrosius' Utopia

In $1997 / 8$, a special exhibition in the National Gallery in London celebrated the completion of the cleaning and restoration of the painting of Jean de Dinteville and Georges de Selve, which is called The ambassadors (NG 1314). The exhibition was accompanied by an explanatory publication $^{2}$ sponsored, as was the exhibition, by Esso UK plc. This work, the fifth in the Making and meaning series, "place(d) the newly restored picture in its technical, scientific, and historical context', and considerable attention was paid to the skull in the foreground, the oblique slash of which is such a challenging enigma in the composition. To illustrate how the effect was achieved, both photographic and computer regenerated skull images of Hans' anamorphic skull are shown, and there is discussion of its meaning as a memento mori, a reminder of mortality.

Ambrosius' own teasing memento mori was given wide exposure in 1998, when Peter Ackroyd published his Life of Thomas More ${ }^{3}$ and used the 1518 map of Utopia for his full page illustration on the back of the dust cover. It well deserves this exposure, even if its full significance was not recognised, for it is a work the equal of Hans' anamorphic skull.

The first three editions of More's Utopia It is possible to enjoy the privilege of examining examples of the first three editions of More's Utopia in the British Library, Euston Road. These date from 1516 (C27 b30), 1517 (C65 e1, reputedly Henry VIII's own copy), and 1518 (G.2398), and are in very good condition.

The publication of the maps, and Erasmus' input

In December 1516 Thomas More's Utopia was first published in its original Latin text by Thierry Martens of Louvain. More had only completed the manuscript in September, and the publication was overseen by Desiderius Erasmus of Rotterdam, and More's new friend Peter Gilles, (or Aegidius), Town Clerk of Antwerp. This first edition was illustrated with a sketch map of Utopia attributed to the 22-yearold Ambrosius, and entitled UTOPIAE INSULAE FIGURA (Fig. 1). There is no difficulty over the commission being possible, since in 1514/5 Ambrosius and Hans were co-operating on marginal illustrations for a Froben edition of Erasmus' own book In 


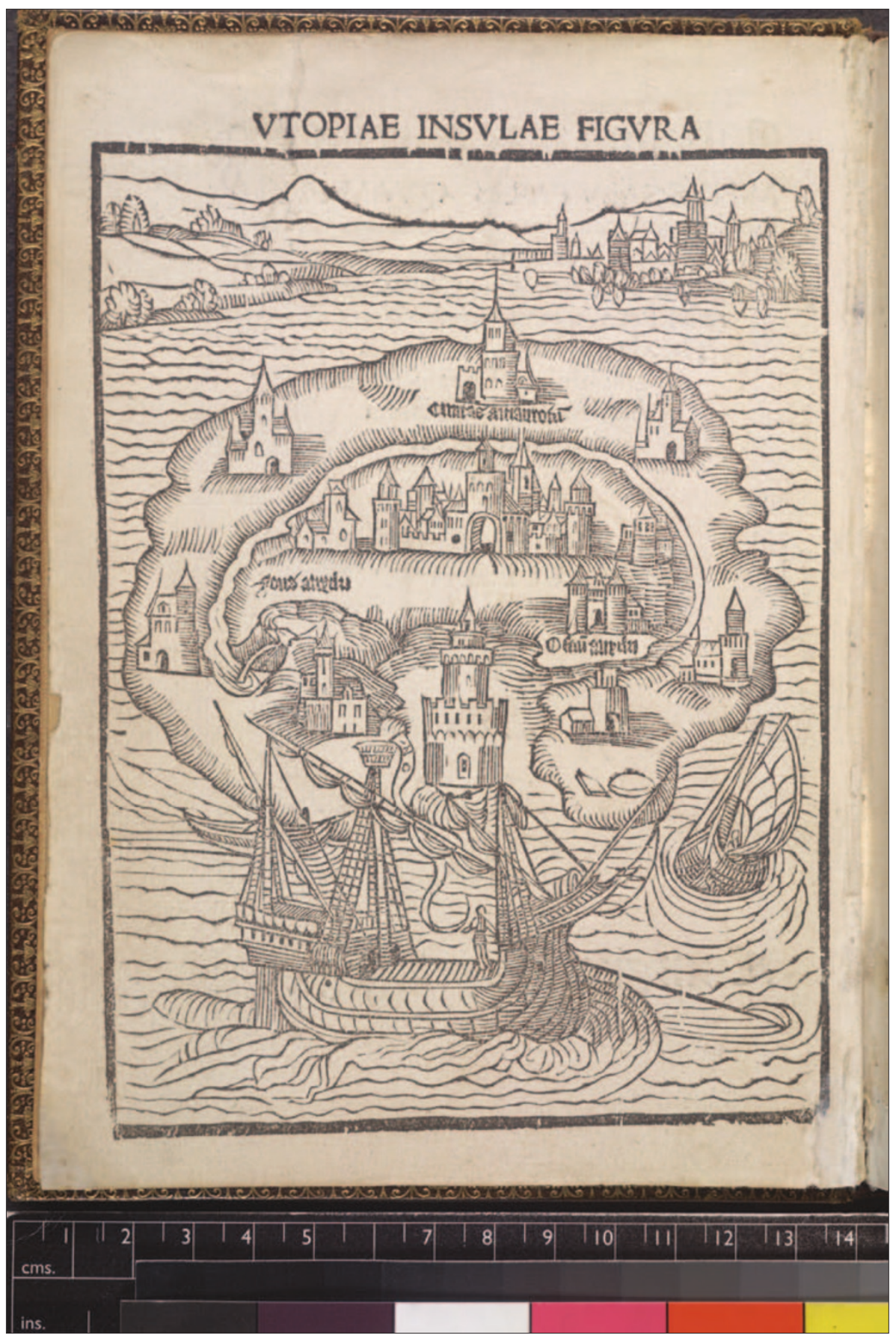

Fig. 1 The Map of Utopia from the first edition of Sir Thomas More's book. Ambrosius Holbein 1516. By kind permission of The British Library. C 27.b.30, frontispiece

praise of folly, which was published in Basel in 1515, and Erasmus, as has been said, was midwifeing the first edition of Utopia. Where a question arises is in comparing the naivety of this first 'map' with the sophistication of the later map.

The map of the 1516 edition is crudely cut, and corresponds only schematically with the text, in scale bearing no relationship to it at all. Ackroyd ${ }^{4}$ points out that the island as described in the book has the same dimensions as England, with the number of city states corresponding to the number of counties, plus London, which latter city the main town of the island resembles. These city states are reduced to six in the map. rocke' which has on it a 'faire and strong towre builded. 5

Three sea vessels are shown. On the left, partially obscured, one appears to be beached; on the right a small craft is scudding along with a crew member indistinctly shown, and in the foreground a ship is at anchor, its hawser tense against a very strong tidal current. A long pennant carries the enigmatic device: $\bullet \mathrm{N} \mathbf{0}$ (altered to $\bullet \mathrm{N} \bullet \mathbf{O} \bullet \mathrm{R}$ on the second map).

The single figure aboard leans rather stiffly against the forecastle and appears to face away from us towards the Island. In the distance a substantial land mass occupies the horizon, and one of the vassal states is shown. Many of the buildings have spires, but none bears any Christian symbol, for the islanders as described by More had no knowledge of the faith, and the whole book is a humanist and perhaps Hellenist apologia, carefully avoiding any confrontation with church doctrine.

Considering the very short time available for the woodcut to be produced, in addition to another woodcut giving the utopian alphabet, devised by More's friend Gilles, which also features in the first edition, the map is not as crude as it might have been. That there is the merest hint of a skull about the whole is more apparent in retrospect, after looking at the second map, than on first sight.

\section{The map in the third edition}

The second edition of Utopia, published in Paris in 1517 by Gilles de Gourmont, did not have any illustrations. Then, in March1518, the third edition, by Froben, was printed in Basel, and this was published bound together with other works by More and Erasmus in a single large volume, on which again Ambrosius and Hans were collaborating for the illustrations.

This edition carried on p.12 a new woodcut of Utopia, this time entitled UTOPIAE INSULAE TABULA (Fig. 2) (Tabula being more specifically a map, where figura is a shape or form), and this time the attribution is definitely made to Ambrosius. (The Oxford companion to art seems to err in naming Hans as the artist, as it gives as its source the 1960 Die Malerfamilie Holbein in Basel $^{6}$ which is clear as to the attribution to Ambrosius, who is not listed in the Companion.)

This second map is not, as Lupton implied, ${ }^{7}$ a re-cutting of the first, and as was said earlier, there is such a difference in realisation between the two as to leave room for doubt that Ambrosius cut the former. If he did, the development in skill in two years is quite remarkable, and the time interval was in fact almost certainly rather less than two years. Lupton (p. lxix) points 
out that on the evidence of pagination and letters of Froben, the Basel edition could have been the second, and could have been published in 1517 before the Paris edition, had Froben not tried to get too much into one volume. The illustration shows just how different in size the two editions are. (Fig. 3)

The new map is a mirror image of the first, from which it clearly derived its inspiration, showing that the drawing on the second block being cut was oriented in the same way as the original print, and not the same way as the original block. There is no evidence of pricking through, or similar mechanical transfer, even the ship in the foreground, which at first sight appears nearly identical, in fact differs in every dimension and is a free copy. The island itself has been transformed, with its visual wit bringing it up to the same standard as the text it accompanies.

At a time when much of book illustration was religious or classical in theme, Ambrosius Holbein's Utopia prints were reckoned to be distinguished by their modernity in showing living people. This lively touch is seen on p. 25 in the same 1518 edition, where another woodcut used to illustrate a previous paper in the $B D J{ }^{8}$ portrays the young John Clement bringing refreshment to the men discussing Utopia (though the mountains of Switzerland sit oddly when surrounding the city of Antwerp).

\section{The idea of the memento mori}

That Ambrosius did not employ a similar visual realism for the map, and based it on the earlier plan, may be taken as evidence that he had something more than mere illustration to convey, and that it was the intention to invite the viewer to examine with care what this may be.

It is possible that what is seen in the second map is the product of a happy chance, and that when Erasmus or Ambrosius saw the resemblance to a skull appearing in the first woodcut, the latter worked it up for the second. The evidence provided by the ship in the foreground as to Ambrosius' intent in representing it as the teeth of the 'skull' in the first map would suggest that the idea was present from the start, as indicated by Holbein's preserving these 'teeth' almost unchanged in the second map.

The more likely explanation is that either from the start, or originating in the accidental appearance of the first map, there was a specific commission from Erasmus to provide a new pun on More's name. This visual pun, based on the Latin for death, Mors, has lasted well, with Mori meaning both 'of More' and 'of death'. The coupling of the words memento mori 'remember death' is still current in English usage long after

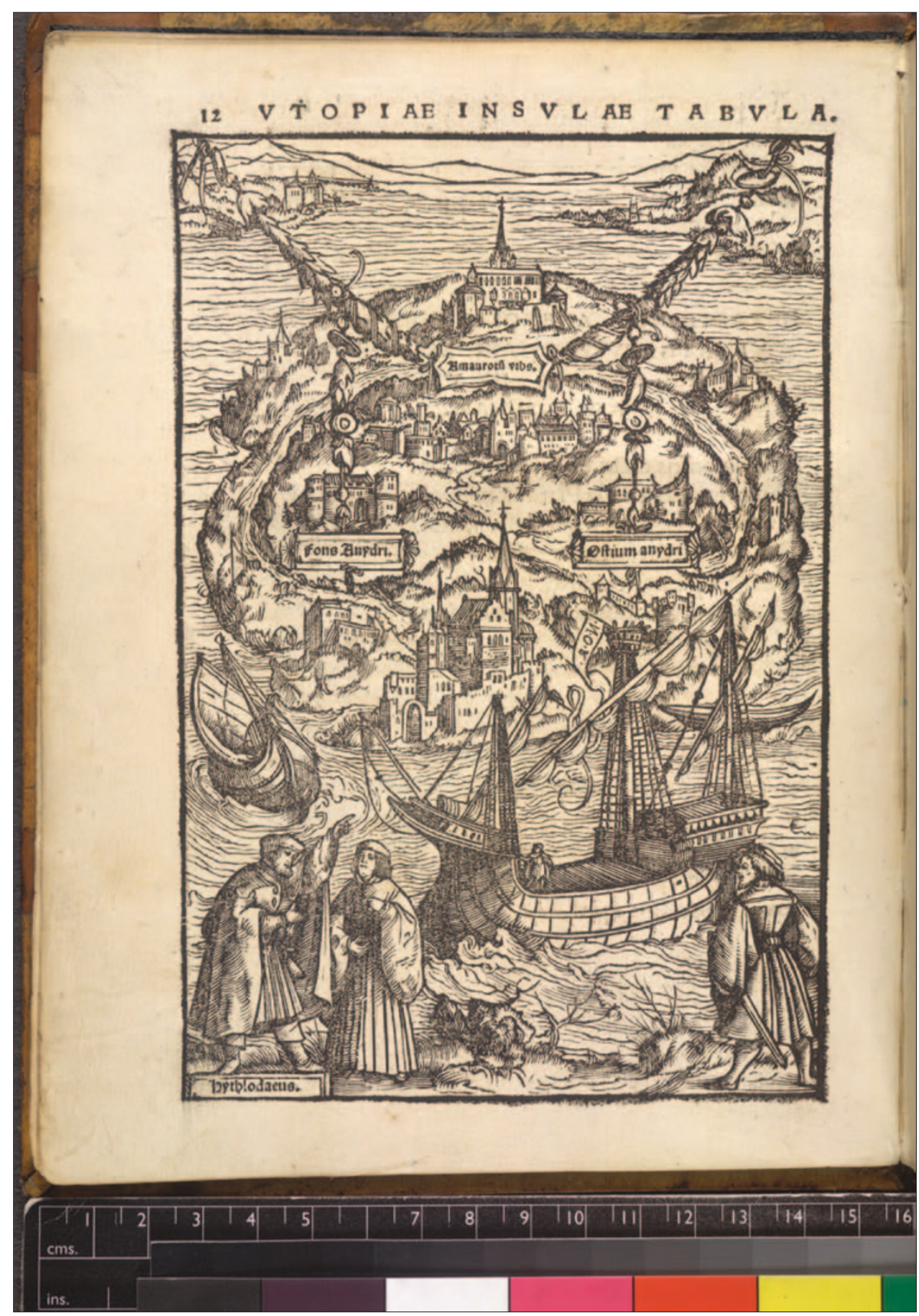

Fig. 2 The Map of Utopia from the third edition of Sir Thomas More's book. Ambrosius Holbein 1518. By kind permission of The British Library. G.2398 p.12

Latin has ceased to be the universal language in which More and Erasmus were as comfortable as their own. The exhortation had existed at least since the eleventh century when a German poem of c.1050 had the title, but quite when death's heads received the generic term is uncertain.

More himself made a similar pun on his own name when dealing with a man who was indebted to him. The debtor, reminding More that after death he would have little use for the money owed, finished 'memento morieris' (remember we will die) to which More replied '...you mean memento mori aeris' - remember More's money. ${ }^{9}$ More and Erasmus much enjoyed this sort of word play, which Erasmus had used in the title of his Encomium moriae (In praise of folly) ${ }^{10}$ of 1509/10, completed at More's house at Bucklersbury on the Thames, ${ }^{11}$ and this gives weight to the suggestion that Erasmus might have primed Ambrosius.

Even in the second edition without illustrations, there is evidence of the ambiguity in the Latin where the magnificent printer's plate on the last page (Fig. 4) has the enigmatic title MORI DE R. .P ('of More, concerning Rei Publicae'?)

\section{The construction of the skull}

The skull in the second woodcut is most apparent to the half-shut eye, and to the 


\section{GENERAL}

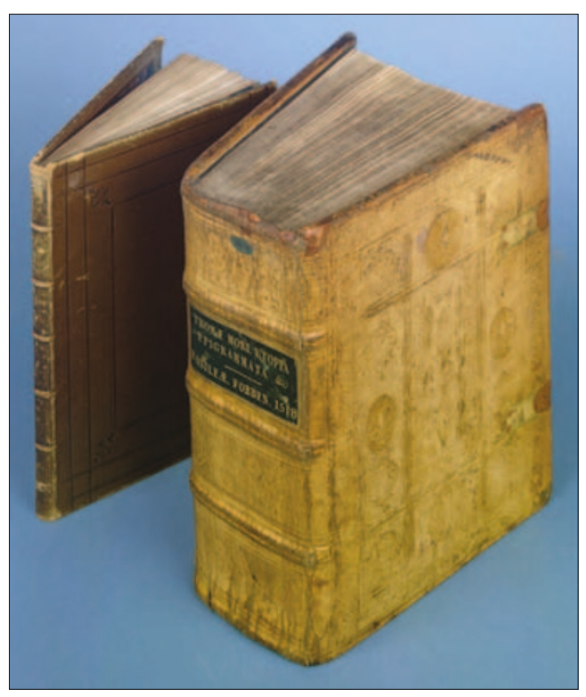

Fig. 3 The first and third editions of Thomas More's Utopia in their original bindings. $\mathrm{G} 2398$, 1516 and $\mathrm{C} 27 \mathrm{~b} 30,1518$. By kind permission of The British Library. Photograph: The British Library.

subliminal effect of a sidelong glance, just as an oblique view is required to see Hans' anamorphic skull. The detail, however, is accessible to methodical analysis, where there is evidence of a particularly artistic genius in Ambrosius' employment both of the old elements present in the first map, in particular the 'ship of teeth' which are the best key to the image, and of the fresh human figures which are introduced to the composition of the new map.

The named figure of Hythlodaeus on the left provides the back of the 'neck', leading the eye down to the 'shoulders'. These shoulders, and the lower border of the jaw bone, are provided by a newly added land mass on which the figures are standing, which, as described in the text, had once been physically joined to the island by an isthmus which 'King Utopus' divided to create the island of Utopia.

A male figure (Lupton suggests Gilles, but the figure is clearly bearded, and Gilles is beardless in the garden scene where he is identified) is moved to what appears to be a most odd position to the right, with an unnatural stance, until it is realised that with the dark shadow of the ship's rudder and heavily outlined clothes he gives shape to the anterior aspect of the mandible of the skull. The third figure, of More himself, contributes both to the spinal column, and the posterior margin of the mandible and its ascending ramus.

The single-masted vessel which has been transferred from the first map, and its wake (or bow-wave, the direction of travel is equivocal), now form an essential element in the composition, the craft

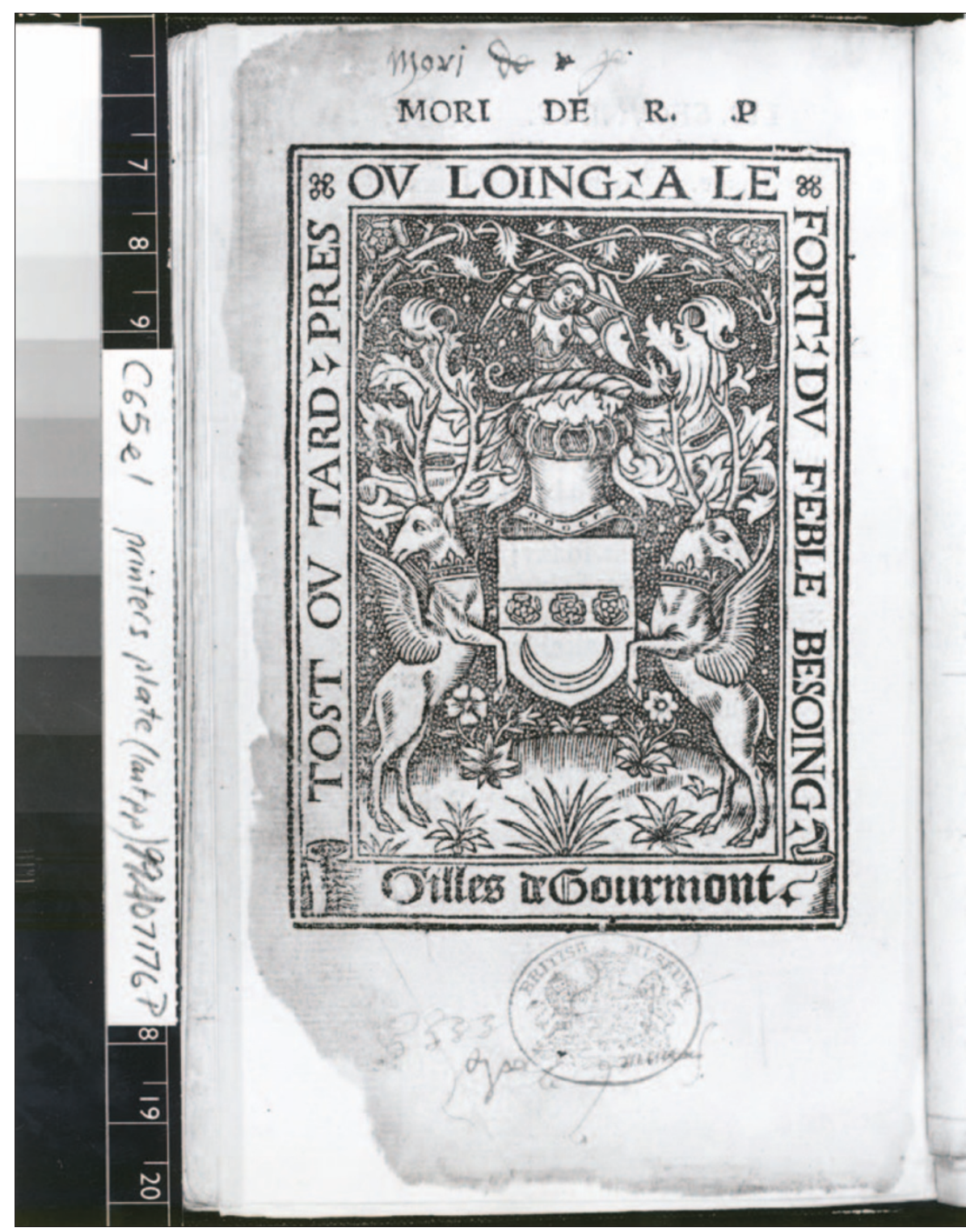

Fig. 4 The Printer's plate from the second edition of More's Utopia, with its enigmatic superscription. 1517. By kind permission of The British Library. C65.e.1.

itself resembling a flick of hair, the emphasised hull outline and dark swell of sea water providing a sweeping line from the shore of the island to Hythlodaeus. On the deck of the large ship, the single figure is transformed, becoming an elegant gentleman, facing the viewer and leaning nonchalantly against the forecastle. The mainmast with its rigging defines the nasal cavity of the skull, while the other two masts with their rigging mark the limits of the upper jaw (maxilla). The forecastle and the bowsprit cheat the eye into perceiving the right cheekbone (zygomatic arch). A similar purpose is served on the left cheek by the beached vessel, which is now barely recognisable as a boat, at a casual glance resembling a furled sail, and which doubles up as the left infra-orbital rim.

On land, the harbour seen in the 1516 map has gone, and the rock which had guarded the original haven, and the fort on it, have been altered in size, orientation, and optical density, and by the addition of an 'eyebrow' hill behind, to form the right eye socket. This trickery by Ambrosius is a reminder of the clever grotesques which were brought to a peak 50 years later for the Hapsburg court by Guiseppe Arcimboldo (1537-93), where fruit, vegetables or weapons are assembled to form a human head.

The enhanced images (Figs 5a and 5b) show how the various rocks and buildings have been turned to face to the left (right from the viewers' perspective) to give the eye sockets and other skull features. The ribs and planking of the ship provide the teeth of a grinning death's head, the lower row of rectangles being not a third row of teeth, but the bony root prominences of the lower incisors and premolars. 


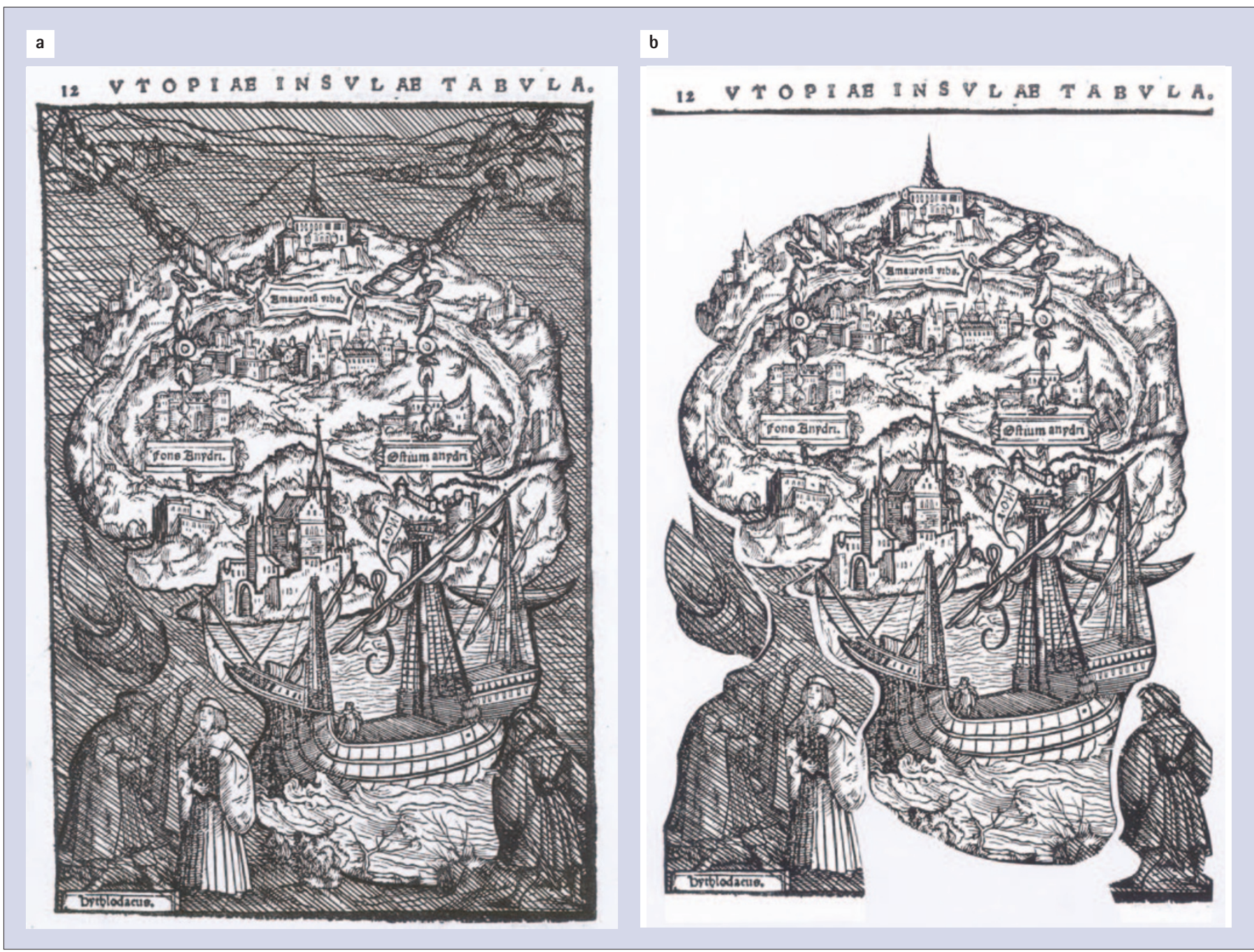

Figs 5a and 5b Enhanced images of Ambrosius Holbein's 1518 Map of Utopia modified from the print in Lupton's The Utopia of Thomas More of 1895. p. 115.

The identification of the land features has been removed from the surface by using labels pendant from elegant swags, and the 'dry' river now has its flow reversed when compared with the 1516 map, with labels for the source and mouth exchanged. Dr Margarete Pfister-Burkhalter $^{12}$ does say that it is possible that the Holbein brothers did not read Latin, on the evidence of others being employed to provide the marginal text notes in the Froben edition of Erasmus' In praise of folly on which they worked together. The reversal of the legends may thus be an error, and not an extension of the joke. If indeed he did not understand Latin, and had not read the text of Utopia, the supposition that Ambrosius had worked up the image independent of the text, as a purely visual pun directed by Erasmus, is reinforced. However labelled, the river now flows out into the open ocean at the right ear, and not, as in the first map, into the harbour, and it identifies the position of the external auditory meatus. Just below this is an inlet where in the skull the mandible would articulate.
Other skulls of the Holbein brothers and their anatomical knowledge

Evidence is preserved of the anatomical knowledge of both brothers, and each was capable of producing either realistic or caricature images of skulls. The best comparative document is the definitive illustrated catalogue ${ }^{13}$ produced for the exhibition Der Malerfamilie Holbein in Basel which, as part of the $500^{\text {th }}$ anniversary of the University, was held in Basel from 4 June to 25 September, 1960. From this exhaustive catalogue it is possible to see that the Utopia map is stylistically unique.

Alternative conjectural meanings for the Utopia skull

Although the main meaning seems to be the 'mori' pun, there is no documentary evidence for this and other reasons for showing a skull should at least be considered. No other of the several illustrations in the Froben edition is anything like the map, and so as has already been said, it invites examination for other messages and meanings as an intellectual puzzle much less clear to the modern viewer, just as the meaning of Hans' anamorphic skull is enigmatic, and has led to much debate.

Teasing these meanings out at a distance of 500 years is risky, but the sixteenth century viewer might have perceived in the image the meaning that the Humanist Reformation text of the book was a product of man's mortal mind, rather than the eternal certainty of God, and that is why it is shown originating from within the skull of a man, although this is diverted by the alteration of the second map to include the Christian symbolism which is absent in the 1516 'map'.

It could equally be argued that as the Reformation took hold, the skull meant that holding such ideas as the book contained was to risk death. This is not unlikely, as Hans, who had illustrated an edition of Luther's Bible (1520), had had to delay the publication of his Reformation Dance of death series from 1526 until 1538. If this danger of the text was apparent 10 years earlier to Ambrosius he was prescient to a remarkable degree, but it cannot be argued 
both that he did not understand Latin, and that he rather than Erasmus was the advanced theological politician and philosopher.

However, if these tentative interpretations occur to a twenty-first century viewer observing the woodcut, as they did earlier to the authorities of the Catholic church who placed Utopia on their list of forbidden books, they would have been likely to have occurred also as interpretations to its contemporaries, an example of a work of art taking on a darker life of its own not necessarily consciously intended by the artist and Erasmus, who could as easily have been seeking only a witty pun.

\section{The interpretation as original}

An essay of this sort must carry a caveat. Although the author is not aware of any previous interpretation of Ambrosius Holbein's map of Utopia as a skull, and recent exhaustive publications on the work of More, Erasmus, Hans Holbein ${ }^{14,15}$ and The Ambassadors ${ }^{16}$ barely mention Ambrosius, 500 years have passed.
In this time many reproductions of the Utopia maps, and many commentaries on More's book in languages which the author does not read, make it impossible to lay certain claim to originality in seeing the skull beneath the paper's skin.

Such originality as can be claimed with certainty lies in the use of the specialist techniques of dentistry and dental radiographic anatomy when looking at the maps, and placing Ambrosius Holbein alongside Hans as a genius of Renaissance art.

The assistance of Karin Hale for translation, Dr William Jenkins for research in Basel, Christina Mackwell, Senior Assistant Librarian at Lambeth Palace library for research on memento mori, and Kay Walters, Librarian at the Athenaeum, is gratefully acknowledged. The British Library kindly gave permission for reproductions.

1. Young S. Annals of the barber surgeons. pp80-84. London: Blades East \&t Blades, 1890.

2. Foister S, Roy A, Wyld M. Making and meaning. Holbein's Ambassadors. London: The National Gallery Company Limited, 1997.

3. Ackroyd P. The life of Thomas More. London: Chatto \&t Windus, 1998

4. Ackroyd P. The life of Thomas More. p 167. London: Chatto \& Windus, 1988.
5. Robynson R. (Translations.) London: Abraham Wele, 1551.

6. Basel University. Die malerfamilie Holbein in Basel. pp 156,161. 1960

7. Lupton J H. The Utopia of Thomas More in Latin and the English of Robynson's translation of 1551. Oxford, 1895.

8. Bishop M, Gelbier S. Ethics and utopia; public health theory and practice in the sixteenth century: An essay comparing the Henrician Medical Act of 1540 and More's 1530 ordinances, with Thomas More's novel 'Utopia' of 1516. Br Dent J 2003; 195: 251.

9. More C. The life of Sir Thomas More. pp 190-1. 1828. In Routh E M G Sir Thomas More and his friends. 1477-1535. p 109. London: Oxford University Press, 1934.

10. Miller C H. Desiderius Erasmus; The praise offolly. New Haven and London: Yale University Press, 1979.

11. Erasmus D. Moria (or Encomium Moriea). $1^{\text {st }} \mathrm{ed}$. $1^{\text {st }}$ authorised ed Paris, 1511. Paris: Ascensian Press, 1512. Basel: Johann Froben, 1515.

12. Pfister-Burkhalter M. Hans Holbein der jungere. In Basel University Die malerfamilie Holbein in Basel. p 217. 1960

13. Gantner J. Reinhardt H. Schmidt G et al. Die malerfamilie Holbein in Basel. Basel University, 1960.

14. Bäschmann O, Greiner P. Hans Holbein. London Reaktion Books, 1997.

15. Holbein, H. Painting prints and reception Washington: National Gallery of Art. Yale Studies in the History of Art 60.

16. North J. The Ambassador's secret. Holbein and the world of the Renaissance. London: Hambledon and London, 2002. 